Originally published as:

Linke, S., MacKay, W.G., Scott, C., Wallace, P., Niedrig, M.

Second external quality assessment of the molecular diagnostic of West Nile virus: Are there improvements towards the detection of WNV?

(2011) Journal of Clinical Virology, 52 (3), pp. 257-260.

DOI: $10.1016 / \mathrm{j} . j c v .2011 .08 .010$

This is an author manuscript.

The definitive version is available at: http://www.sciencedirect.com/ 


\title{
Second external quality assessment of the molecular diagnostic of West Nile virus: Are there improvements towards the detection of WNV?
}

\author{
Sonja Linke ${ }^{a}$, William G. MacKay ${ }^{b}$, Calum Scott ${ }^{b}$, Paul Wallace ${ }^{b}$, Matthias Niedrig ${ }^{a}$ \\ ${ }^{a}$ Robert Koch Institute, Nordufer 20, 12353 Berlin, Germany \\ ${ }^{\mathrm{b}}$ Quality Control for Molecular Diagnostics (QCMD), The Altum Building, Todd Campus, West of \\ Scotland Science Park, Glasgow G20 OXA, Scotland, United Kingdom
}

\begin{abstract}
Background: WNV epidemics occur worldwide, new WNV isolates were isolated in southern-east Europe belonging to WNV lineage 2. A first international proficiency study on WNV indicted that some laboratories were not able to detect WNV lineage 2 virus genome by their PCR diagnostic assays. Therefore an actual External Quality Assessment with both virus lineages was performed to monitor the improvements in molecular diagnostics.
\end{abstract}

Objectives: To asses the proficiency of laboratories to detect West Nile virus with molecular diagnostic tests.

Study design: A test panel of different WNV isolates and virus dilutions was given to 26 laboratories to test the samples with their routine diagnostic methods.

Results: Twenty-one participating laboratories provided 28 data set results. WNV lineage 1 was detected with high overall efficiency of 92\% (67.9-100\%) but two different WNV lineage 2 strains were detected at lower rates (mean $=73 \%, 67.9-75 \%$ ) by the different $P C R$ assays. 93\% of the laboratories were able to detect a WNV lineage 1 with a concentration of $1.2 \times 10^{4}$ copies $/ \mathrm{ml}$ but the detection rate was decreased to $68 \%$ for $1.2 \times 10^{3}$ copies $/ \mathrm{ml}$. One laboratory generated false-positive result from the non-virus control samples and $29 \%$ of the datasets showed false-positive results for non-WNV flavivirus samples.

Conclusions: The WNV EQA showed an improved proficiency of laboratories as compared to the first $E Q A$. However, the data suggest that problems in the detection of both lineages were still present since the first proficiency test was performed in 2006. Further proceedings versus the detection of both lineages are needed particularly for in-house assays.

\begin{abstract}
Abbreviations
WNV, West Nile virus; PCR, polymerase chain reaction; EQA, external quality assessment; VTM, virus transport medium; ECDC, European Centre for Disease Prevention and Control
\end{abstract}




\section{Background}

West Nile virus (WNV) belongs to the genus Flavivirus in the family Flaviviridae. ${ }^{1}$ Phylogenetic studies based on amino acid substitutions or deletions in the envelope proteins show that WNV can be separated into two major lineages. WNV lineage 1 is responsible for epidemics in the western hemisphere, and it is assumed that these viruses are particularly pathogenic for vertebrates such as birds, humans and horses. ${ }^{2}$ WNV lineage 2 is endemic in Southern Africa and Madagascar ${ }^{3}$ and it was postulated to be non-pathogenic in horses and is maintained in endozootic cycles. ${ }^{[4]}$ and ${ }^{[5]}$ New studies show that variants of WNV lineage 2 can be neuroinvasive in mice or can cause severe symptoms in horses or humans. ${ }^{[3],[6] \text { and }[7]}$ Recently WNV genotype lineage 2 became more prevalent in Europe and new strains were isolated in Central Europe. ${ }^{8}$ In summer 2010 WNV epidemics occurred in Southeast Europe (Greece, Turkey, Russia, and Romania). The epidemic in Greece might be causative associated with WNV lineage 2 viruses. ${ }^{9}$ In 2006 a first proficiency study was performed regarding the molecular detection of WNV. Laboratories generally showed a good performance in detecting WNV lineage 1 but $43 \%$ of laboratories were unable to detect WNV lineage $2 .{ }^{10}$ The recent external quality assessment (EQA) should be seen as a confirmation of improved WNV molecular diagnosis versus detection of both WNV lineages and the specificity of the WNV molecular diagnostic.

\section{Objectives}

The aim of this EQA was to evaluate the proficiency of laboratories to detect West Nile virus with molecular diagnostic tests.

\section{Study design}

The WNV EQA Programme test panel consisted of nine coded samples containing WNV viruses of lineages 1 and 2 plus 3 control samples. Lineage 1 WNV was represented by WNV NY99 whereas for WNV lineage 2 WNV Uganda B956 (kindly provided by G. Wengler), and WNV (goshawk-Hungary/04 kindly provided by Emöke Ferenzi) were used. Two mixed samples consisting of different other flaviviruses like Japanese encephalitis virus, Dengue virus 1, 2, and 4 or rather Dengue 3, Yellow fever virus 17D, and Tick borne encephalitis virus were added to the panel to analyse the specificity of the PCR assays. All virus samples were inactivated by heat $\left(56^{\circ} \mathrm{C}, 1 \mathrm{~h}\right)$ and gamma irradiated before diluted in virus transport medium (VTM; $10 \%$ fetal calf serum in Dulbecco's Modified Eagle's Medium) to concentrations of $1.2 \times 10^{7}$ to $1.2 \times 10^{3}$ copies $/ \mathrm{ml}$. Testing was performed on all samples in their final form which showed that they performed to expectation. The lyophilised samples were shipped to the participants in July 2010.

26 laboratories from 12 European and non-European countries received the EQA samples from which 21 returned one or two data stets of results obtained by different PCR assays. The laboratories were asked to test the panel samples by their routine molecular diagnostic WNV test and to provide a dataset for qualitative and/or quantitative results. The data were analysed in order to asses the proficiency in the detection of WNV and to asses the performance in distinguishing WNV from other flaviviruses.

\section{Results}

Twenty-one participating laboratories (81\%) returned 28 datasheets of which $10(36 \%)$ were qualitative and quantitative. Eight of these 28 datasets (29\%) stated conventional in-house polymerase chain reaction (PCR), 7 (25\%) commercial real time assays and $13(46 \%)$ laboratories used in-house real time assays.

Aim of this EQA was to assess the proficiency of laboratories to detect WNV lineage 1 in concentrations between $1.2 \times 10^{7}$ and $1.2 \times 10^{4}$ copies/mI WNV NY 99 virus (\#1-5) and WNV genotype lineage 2 isolate WNV goshawk-Hungary/04 (\# and WNV Uganda B956 in concentrations of $1.1 \times 10^{5}$ to $7.3 \times 10^{6}$ copies $/ \mathrm{ml}$ and one negative control respectively by all laboratories (Table $1 ; \# 7-$ 9). 
When applying these criteria, $75 \%$ of the laboratories passed the minimum requirements for successful participation. Considering that the sensitivity for a diagnostic PCR should be roughly $10^{3}$ copies/ml and that WNV lineage 2 is only detected by $68-75 \%$ of the laboratories a significant improvement is recommended for these laboratories (Table 1). Regarding the technology type and their sensitivity, commercial real time methods detected all WNV samples accurately. In-house real time PCR methods detected most of the dilution series correctly. Using conventional PCR for WNV detection false negative results of the different concentrated WNV solutions were given for three samples.

Looking at the details of the proficiency to detect WNV lineage 2, all commercial assays were able to detect both isolates (\#7-9). 54\% of the laboratories providing results based on in-house real-time PCR were able to detect the samples of WNV lineage 2 and $46 \%$ were able to detect the second strain Uganda B956. Using conventional PCR $88 \%$ of the datasheets described the detection of WNV goshawk and $75 \%$ were able to detect WNV Uganda B956.

Two samples of the EQA panel contained heterologous non-WNV flaviviruses to test the specificity of the WNV diagnostics. Four out of 28 datasets generated false-positive WNV results for each non-WNV flavivirus sample (\#10,\#11). These false-positive results can be correlated with PCR systems targeting the following genes: $3^{\prime} \mathrm{UTR}, 5^{\prime} \mathrm{UTR}$, envelope protein, NS5 and target genes not otherwise reported (Table 2).

The VTM only negative sample was reported false positive by one participant (4\%) using a conventional in-house PCR targeting the NS5 region pointing to a basic contamination problem in the lab setting (Table 2).

\section{Discussion}

Since WNV linage 2 was recently introduced into Europe the detection of both lineages by PCR is mandatory for a diagnostic laboratory. ${ }^{8}$ The unsatisfying results of the first external quality assessment study for quality of PCR diagnostic of WNV genome clearly show the gaps and needs to improve the assay perfomance. ${ }^{10}$ In this study 16 out of 30 laboratories failed to detect linage 2 . In contrast to the WNV outbreak 1996-1997 in Romania caused by linage 1 the WNV outbreak in Northern Greece in 2010 was also related to linage 2 and was accompanied by some death in older people. ${ }^{11}$ The presented quality assessment study still demonstrates that one third of the laboratories must improve their PCR assays regarding detection of linage 2 to allow the detection of all relevant WNV strains at risk for future outbreaks.

Besides the specificity of WNV diagnostics the EQA monitors the sensitivity of PCR methods. A WNV concentration of $1.2 \times 10^{4}$ copies $/ \mathrm{ml}$ was detected by $93 \%$ whereas $1.2 \times 10^{3}$ copies $/ \mathrm{ml}$ were detected only by $68 \%$ of the laboratories. This is a clear loss of sensitivity, which affected only in-house PCR systems. Results of WNV screening in blood donors showed that the viral load of WNV in plasma samples was between $1.1 \times 10^{2}$ to $7.6 \times 10^{3}$ copies $/ \mathrm{ml}$ and $5.7 \times 10^{1}$ to $8.4 \times 10^{2}$ copies RNA $/ \mathrm{ml}$ respectively. ${ }^{[12]}$ and [13] In fact, plasma is often used for WNV diagnostics, precaution is necessary concerning the sensitivity of WNV PCR method.

Incorrect results were obtained with non-WNV Flaviviruses and with the true negative control, which was already stated by the EQA in 2006.

In conclusion this EQA provided interesting results regarding the proficiency of laboratories involved in molecular detection of WNV. Laboratories must improve their performances in the sensitive detection and correct amplification of WNV genotype lineage 2 so that inaccuracies in diagnosis can be avoided. Further they should monitor their performances regularly and attend EQA programmes. 


\section{Funding}

None.

\section{Competing interests}

None declared.

\section{Ethical approval}

Not required.

\section{Acknowledgements}

The EQA was performed by the QCMD in collaboration with the European Network for Diagnostics of "Imported" Viral Diseases (ENIVD). They would like to thank all of the laboratories who participated in this study. We thank Anette Teichmann and Patricia Bußmann for excellent technical assistance in virus preparation. 


\section{References}

1. Kuno G, Chang GJ, Tsuchiya KR, Karabatsos N, Cropp CB. Phylogeny of the genus Flavivirus. J Virol 1998;72:73-83.

2. Solomon T, Ooi MH, Beasley DW, Mallewa M. West Nile encephalitis. BMJ 2003;326:865-9.

3. Botha EM, Markotter W, Wolfaardt M, Paweska JT, Swanepoel R, Palacios G, et al. Genetic determinants of virulence in pathogenic lineage 2 West Nile virus strains. Emerg Infect Dis 2008;14:222-30.

4. Lanciotti RS, Roehrig JT, Deubel V, Smith J, Parker M, Steele K, et al. Origin of the West Nile virus responsible for an outbreak of encephalitis in the northeastern United States. Science 1999;286:2333-7.

5. Petersen L, Roehring J. West Nile virus: a reemerging global pathogen. Emerg Infect Dis 2001;7:611-4.

6. Beasley DW, Li L, Suderman MT, Barrett AD. Mouse neuroinvasive phenotype of West Nile virus strains varies depending upon virus genotype. Virology 2002;296:17-23.

7. Venter M, Human S, Zaayman D, Gerdes GH, Williams J, Steyl J, et al. Lineage 2 west nile virus as cause of fatal neurologic disease in horses. South Africa Emerg Infect Dis 2009;15:877-84.

8. Bakonyi T, Ivanics E, Erdélyi K, Ursu K, Ferenczi E, Weissenböck H, et al. Lineage 1 and 2 strains of encephalitic West Nile virus, central Europe. Emerg Infect Dis 2006;12:618-23.

9. ProMED-mail. West Nile Virus_Eurasia (05): GR, HU, AT. ProMED-mail 2010; 14 September: 20100914.3312. http://www.promedmail.org; 2010 [accessed 13.09.10.].

10. Niedrig M, Linke S, Zeller H, Drosten C. First international proficiency study on West Nile virus molecular detection. Clin Chem 2006;52:1851-4.

11. ECDC, ECDC THREAT ASSESSMENT Outbreak of West Nile virus infection in Greece; JulyAugust 2010.

12. Rios M, Daniel S, Chancey C, Hewlett IK, Stramer SL. West Nile virus adheres to human red blood cells in whole blood. Clin Infect Dis 2007;45: 181-6.

13. Pfleiderer C, Blümel J, Schmidt M, Roth WK, Houfar MK, Eckert J, et al. West Nile virus and blood product safety in Germany. J Med Virol 2008;80: 557-63. 


\section{Tables and Figures}

Table 1. Number of correct qualitative results per panel member and technology type.

\begin{tabular}{|c|c|c|c|c|c|c|c|c|c|c|}
\hline \multirow[t]{5}{*}{ No. } & \multirow[t]{5}{*}{ Sample content } & \multirow{5}{*}{$\begin{array}{l}\text { Sample } \\
\text { concentration } \\
\text { [copiesiml] }\end{array}$} & \multirow{3}{*}{\multicolumn{2}{|c|}{$\begin{array}{l}\text { Total } \\
\text { datasets } \\
n=28\end{array}$}} & \multirow{2}{*}{\multicolumn{2}{|c|}{$\begin{array}{l}\text { Conventional } \\
\text { PCR }\end{array}$}} & \multicolumn{4}{|c|}{ Real time PCR } \\
\hline & & & & & & & & & & \\
\hline & & & & & & & & & & \\
\hline & & & \multirow[b]{2}{*}{$n$} & \multirow[b]{2}{*}{$\%$} & \multicolumn{2}{|c|}{ In-house $n=8$} & \multicolumn{2}{|c|}{ Commercial ${ }^{\mathrm{b}} n=7$} & \multicolumn{2}{|c|}{ In-house $c h=13$} \\
\hline & & & & & $n$ & $\%$ & $n$ & $\%$ & $n$ & $\%$ \\
\hline 1. & WN Virus NY99 & $1.2 \times 10^{7}$ & 28 & 100.0 & 8 & 100.0 & 7 & 100.0 & 13 & 100.0 \\
\hline 2. & $\begin{array}{l}\text { GenBankNo: } \\
\text { DQ211652 }\end{array}$ & $1.2 \times 10^{6}$ & 27 & 96.4 & 7 & 87.5 & 7 & 100.0 & 13 & 100.0 \\
\hline 3. & WNN Virus NY99 & $1.2 \times 10^{6}$ & 28 & 100.0 & 8 & 100.0 & 7 & 100.0 & 13 & 100.0 \\
\hline 4. & $\begin{array}{l}\text { GenBankNo: } \\
\text { DQ211652 }\end{array}$ & $1.2 \times 10^{6}$ & 26 & 92.9 & 7 & 87.5 & 7 & 100.0 & 12 & 92.3 \\
\hline 5. & Wow virus NY9g & $1.2 \times 10^{4}$ & 26 & 92.9 & 6 & 75.0 & 7 & 100.0 & 13 & 100.0 \\
\hline 6. & $\begin{array}{l}\text { GenBankNo: } \\
\text { DQ211652 }\end{array}$ & $1.2 \times 10^{3}$ & 19 & 67.9 & 2 & 25.0 & 7 & 100.0 & 10 & 76.9 \\
\hline 7. & $\begin{array}{l}\text { WN Virus goshawk- } \\
\text { Hungary } 04\end{array}$ & $7.3 \times 10^{6}$ & 21 & 75.0 & 7 & 87.5 & 7 & 100.0 & 7 & 53.8 \\
\hline 8. & $\begin{array}{l}\text { GenBankNo: } \\
\text { DQ116961 }\end{array}$ & $7.3 \times 10^{6}$ & 21 & 76.0 & 7 & 87.5 & 7 & 100.0 & 7 & 53.8 \\
\hline 9. & $\begin{array}{l}\text { WWN Virus iwNV } \\
\text { Uganda B956 } \\
\text { GenBank No: } \\
\text { AY532665 }\end{array}$ & $1.1 \times 10^{6}$ & 19 & 67.9 & 6 & 75.0 & 7 & 100.0 & 6 & 46.2 \\
\hline 10. & $\begin{array}{l}\text { Non-iuNV } \\
\text { Flaviviruses JEV, } \\
\text { DEN1, DEN, 2, DEN } \\
4\end{array}$ & Each $1.0 \times 10^{6}$ & 24 & 85.7 & 5 & 62.5 & 6 & 85.7 & 13 & 100.0 \\
\hline 11. & $\begin{array}{l}\text { Non-iunN } \\
\text { Flaviviruses DEN } 3 \text {, } \\
\text { YF, TBE }\end{array}$ & Each $1.0 \times 10^{6}$ & 24 & 85.7 & 6 & 75.0 & 6 & 85.7 & 12 & 92.3 \\
\hline 12. & WNV negative VTM & & 27 & 96.4 & 7 & 87.5 & 7 & 100.0 & 13 & 100.0 \\
\hline
\end{tabular}

Sample content: viral content of the panel samples; Total datasets: number and percentage of datasets reporting the correct qualitative result for each panel sample. A breakdown of the results for all datasets is also provided based on technology type.

a Details not presented.

b QIAGEN artus WWN' LC RTPCR Kit ( $n=3)$, QIAGEN artus WNNW TM RT PCR Kit $(n=1)$, QIAGEN RealÄrt Wiest Nile virus $(n=1)$, Roche, COB,AS TaqScreen Wiest Nile virus Test $(n=1)$, TIB MOLBIOL LightMixKit Wiest Nile virus $(n=1)$.

c Details not presented

* VTTM = virus transport medium 
Table 2. Analysis of the qualitative data by assay target gene, out of the 28 datasets $19(67.9 \%)$ contained information on the target gene.

\begin{tabular}{|c|c|c|c|c|c|c|c|c|c|c|c|c|c|c|c|c|}
\hline & \multirow{4}{*}{$\begin{array}{l}\text { Sample } \\
\text { content }\end{array}$} & \multirow{4}{*}{$\begin{array}{l}\text { Sample } \\
\text { concentration, } \\
\text { [copies iml] }\end{array}$} & \multirow{3}{*}{\multicolumn{2}{|c|}{$\begin{array}{l}\text { Total } \\
\text { data-sets } \\
n=2\end{array}$}} & \multirow{2}{*}{\multicolumn{2}{|c|}{$\begin{array}{l}3 \text { UTR } \\
n=3\end{array}$}} & \multirow{2}{*}{\multicolumn{2}{|c|}{$\begin{array}{l}5 \text { UTR } \\
n=4\end{array}$}} & \multicolumn{2}{|c|}{$E n=2$} & \multirow{2}{*}{\multicolumn{2}{|c|}{$\begin{array}{l}\text { NS5 } \\
n=7\end{array}$}} & \multicolumn{2}{|c|}{ Other $n=3$} & \multirow{3}{*}{\multicolumn{2}{|c|}{$\begin{array}{l}\text { Not } \\
\text { reported } \\
n=9\end{array}$}} \\
\hline & & & & & & & & & & & & & & & & \\
\hline & & & & & \multirow[b]{2}{*}{$n$} & \multirow[b]{2}{*}{$\%$} & \multirow[b]{2}{*}{$n$} & \multirow[b]{2}{*}{$\%$} & \multirow[b]{2}{*}{$n$} & \multirow[b]{2}{*}{$\%$} & \multirow[b]{2}{*}{$n$} & \multirow[b]{2}{*}{$\%$} & \multirow[b]{2}{*}{$\pi$} & \multirow[b]{2}{*}{$\%$} & & \\
\hline & & & $\pi$ & $\%$ & & & & & & & & & & & $n$ & $\%$ \\
\hline 1. & WN Virus & $1.2 \times 10^{7}$ & 28 & 100.0 & 3 & 100.0 & 4 & 100.0 & 2 & 100.0 & 7 & 100.0 & 3 & 100.0 & 9 & 100.0 \\
\hline 2. & NY99 & $1.2 \times 10^{6}$ & 27 & 96.4 & 3 & 100.0 & 4 & 100.0 & 2 & 100.0 & 6 & 85.7 & 3 & 100.0 & 9 & 100.0 \\
\hline 3. & WNN Virus & $1.2 \times 10^{6}$ & 28 & 100.0 & 3 & 100.0 & 4 & 100.0 & 2 & 100.0 & 7 & 100.0 & 3 & 100.0 & 9 & 100.0 \\
\hline 4. & NY99 & $1.2 \times 10^{6}$ & 26 & 92.9 & 3 & 100.0 & 3 & 75.0 & 2 & 100.0 & 6 & 85.7 & 3 & 100.0 & 9 & 100.0 \\
\hline 5. & WN Virus & $1.2 \times 10^{4}$ & 26 & 92.9 & 3 & 100.0 & 4 & 100.0 & 2 & 100.0 & 5 & 71.4 & 3 & 100.0 & 9 & 100.0 \\
\hline 6. & NY99 & $1.2 \times 10^{3}$ & 19 & 67.9 & 2 & 66.7 & 1 & 25.0 & 2 & 100.0 & 3 & 42.9 & 3 & 100.0 & 8 & 88.9 \\
\hline 7. & Won Virus & $7.3 \times 10^{6}$ & 21 & 75.0 & 3 & 100.0 & 3 & 75.0 & 1 & 50.0 & 5 & 71.4 & 2 & 66.7 & 7 & 77.8 \\
\hline 8. & Hungaryi04 & $7.3 \times 10^{6}$ & 21 & 75.0 & 3 & 100.0 & 3 & 75.0 & 1 & 50.0 & 5 & 71.4 & 2 & 66.7 & 7 & 77.8 \\
\hline 9. & $\begin{array}{l}\text { Wo'N Virus } \\
\text { WWN } \\
\text { Uganda } \\
\text { B956 }\end{array}$ & $1.1 \times 10^{6}$ & 19 & 67.9 & 2 & 66.7 & 3 & 75.0 & 1 & 50.0 & 6 & 85.7 & 1 & 33.3 & 6 & 66.7 \\
\hline 10. & $\begin{array}{l}\text { JEV, DEN } \\
1,-2,-4\end{array}$ & $\begin{array}{l}\text { Each } \\
1.0 \times 10^{6}\end{array}$ & 24 & 85.7 & 3 & 100.0 & 3 & 75.0 & 1 & 50.0 & 5 & 71.4 & 3 & 100.0 & 9 & 100.0 \\
\hline 11. & $\begin{array}{l}\text { DEN 3, YF, } \\
\text { TBE }\end{array}$ & $\begin{array}{l}\text { Each } \\
1.0 \times 10^{6}\end{array}$ & 24 & 85.7 & 2 & 66.7 & 4 & 100.0 & 2 & 100.0 & 5 & 71.4 & 3 & 100.0 & 8 & 88.9 \\
\hline 12. & $\begin{array}{l}\text { ión } \\
\text { negative } \\
\text { VTM- }\end{array}$ & & 27 & 96.4 & 3 & 100.0 & 4 & 100.0 & 2 & 100.0 & 6 & 85.7 & 3 & 100.0 & 9 & 100.0 \\
\hline
\end{tabular}

Sample: QCMD panel sample codes for the samples distributed to participants; Sample content: viral content of the panel samples; Total datasets: number and percentage of datasets reporting the correct qualitative result for each panel sample. A breakdown of the results for all datasets is also provided based on target gene.

* Capsid protein $(\rho=1)$. genomic region for RT stage 233-640 bUase pairs; nested stage 287-390 base pairs corresponding mainlyto the nucleocapsid region ( $n=1)$, pre-membrane protein $(n=1)$.

** VTM $=$ virus transport medium. 